\title{
COMPETENCES OF INNOVATION BROKERS - EXPERIENCES OF THE GOSMART BSR PROJECT
}

\author{
ANNA DYHDALEWICZ ${ }^{\circledR}$ JUSTYNA GRZEŚ-BUKŁAHO
}

\begin{abstract}
A B S TR A C T
The paper attempts to create a universal model of competences for international innovation brokers combining knowledge, skills and attitudes in the context of tasks aimed at internationalisation and development of innovation in SMEs. The article reviews the relevant literature, uses a bibliometric study identifying the brokers' attributes, innovation and competences using the VOSviewer tool, and presents qualitative research - a case study of the GoSmart BSR project. The paper resulted in a synthetic model of competences for international innovation brokers, taking a holistic approach to defining competences. The presented model is a synthesis of previous experiences with formulating competences for international innovation brokers. The elements of the model of competences and their components are equally significant for accelerating the internationalisation of SMEs and implementing innovations. This model is practical and universal, so it can be used in various organisations working towards the internationalisation and innovation of SMEs. Lessons learned from the GoSmart BSR project can be an inspiration to experiment and introduce new ideas and concepts. The identified competence elements can be considered universal and key in the work of an international innovation broker, but neither their list nor competence components are exhaustive. Therefore, the issues discussed in the article may form the basis for further research in this area.
\end{abstract}

KEY WORDS

innovation brokers, internationalisation, GoSmart BSR project, competences

10.2478/emj-2021-0034
Justyna Grześ-Bukłaho

Bialystok University of Technology, Poland ORCID 0000-0002-5083-1879

Corresponding author: e-mail: j.grzes@pb.edu.pl

Anna Dyhdalewicz

Bialystok University of Technology, Poland ORCID 0000-0001-6605-961X

\section{INTRODUCTION}

The article attempts to create a universal model of individual competences for international innovation brokers combining knowledge, skills and attitudes in the context of specific tasks aimed at internationalisa- tion and innovation development of SMEs. The article uses a bibliometric study identifying broker attributes, the VOSviewer tool for innovation and competences, and a case study for qualitative research. It includes a monographic presentation of a positive case regard-

Dyhdalewicz, A., \& Grześ-Bukłaho, J. (2021). Competences of innovation brokers - experiences of the GoSmart BSR Project. Engineering Management in Production and Services, 13(4), 95-114. doi: 10.2478/emj-2021-0034 
ing a network of cooperating quadruple helix entities in the GoSmart BSR project.

The project addressed the low capacity for innovation in less developed parts of the Baltic Sea Region (BSR) by mutual learning, translating Smart Specialisation Strategies (S3) into practical SME joint actions, and employing good practice from more developed regions. The project is fully integrated with S3 and aims to foster effective transnational cooperation between the industry, the $\mathrm{R} \& \mathrm{D}$ sector and authorities. The main expected results were a functioning and sustainable Transnational Innovation Brokerage System (TIBS) and SME Joint Transnational Smart Strategies (JTSS) implemented across partner regions (Kruse et al., 2019).

The project assumes that building and improving competences of international innovation brokers is a prerequisite for achieving its goals. One project result was the specification of their competences, which are conducive to building internationalisation and innovation in SMEs. This solution focuses on the competences of individual brokers, adapting them to the implementation of project objectives. Therefore, the article presents the contexts for identifying the types of competences for innovation brokers that impact the internationalisation and development of potential innovations in the SME sector in the Baltic Sea Region (Mueller-Using et al., 2020).

In conclusion, the main cognitive goal of this article has been to identify the structure and basic dimensions for the competences of international innovation brokers. The main utilitarian goal of the article is to offer a model of the individual competences necessary for innovation brokers to networks of entities supporting the internationalisation and innovation of SMEs. For the purposes of this article, a definition for the term "competences" is considered from the perspective of an individual (broker) and includes three mutually complementary elements: knowledge, abilities, and attitudes, whereby the knowledge and skills of employees can be created in an organisation. These elements, used and developed in the process of providing intermediation services, lead to the achievement of results consistent with the organisation's goals and strategic intentions.

\section{LITERATURE REVIEW}

The literature on the subject includes a number of different definitions of competences and their classification, relating mainly to managerial competences
(Prahalad \& Hamel, 1990; Moczydłowska, 2008; Brelik \& Żuchowski, 2017; Kupczyk \& Stor, 2017; Bhardwaj \& Punia, 2013; Krajcovicova et al., 2012; Abraham et al., 2001; Patanakul \& Milosevic, 2008; Papulová \& Mokroš, 2007). Competences are most often rooted in specific management models popular at a specific time and adapted to the current knowledge or market situation (Gonczi \& Hager, 2010; Vakola et al., 2007; Staškeviča, 2019). Considering the behavioural concepts, competences from the perspective of an individual are "expectations of the behaviour, skills and other characteristics of employees conducive to achieving success at work" (Jurek, 2012, p. 11). Behaviour that allows for the effective performance of duties is essential. Another approach used today in the Human Performance Technology (HPT) model, created by Gilbert, emphasises the measurement of performed tasks using the performed work results (Chyung, 2005; Stolovitch, 2000). The measure of the results is the relationship between the size of the obtained effects and the incurred expenditure, i.e., the effort related to an activity. With regard to the model of open innovation and the resource theory, to gain competitive advantage, a company should either have unique and valuable resources and appropriate skills or average resources but unique skills. They constitute a competence category in an organisation.

In practice, the functions performed by international innovation brokers are combined with key competences using a practical or situational approach by diagnosing the situation accurately and analysing the organisation's or project's environment and considering the operational conditions of the entities. Contemporary challenges posed by the global environment for the SME sector enterprises are varied (Prasanna et al., 2019; Singh \& Deshmukh, 2008; Mundim et al., 2000). Aiming for development and their possibilities to improve competitiveness, SMEs should consider the opportunities offered by internationalisation combined with creating smart specialisations and innovations (Hogeforster, 2014; Andersson et al., 2004; Edwards et al., 2005). The development of these processes depends on the ability and willingness to cooperate with various entities in the environment, the level of their openness to cooperation, and taking up and participating in joint initiatives. It has become a necessity for small and medium-sized enterprises to develop formal, systematic, multidisciplinary and creative knowledge related to the external environment (Chaochotechuang et al., 2019). These enterprises increasingly seek new knowledge sources. They use the services and knowledge potential of external 
brokers. The roles and functions performed by knowledge brokers require them to have appropriate competences. The important ones allow SMEs to join global cooperation networks for internationalisation and innovation. The system of knowledge brokerage services can be implemented in all areas of socioeconomic life. The literature highlights the following areas related to the role of brokers:

(1) Brokers as participants of innovation processes (knowledge brokers); brokers as intermediaries of knowledge, whose function is primarily to acquire external knowledge and to disseminate it within the unit, primarily for the needs of R\&D team employees and others using this information (Sergeeva \& Liu, 2020). "They are sometimes defined as actors who use their 'in-between' vantage position to support innovation through connecting, recombining and transferring to new contexts otherwise disconnected pools of ideas" (Haas, 2015, p. 1037);

(2) The importance of the network broker subject in relation to corporate innovations, including the social capital issue and the institutional base in the context of building learning regions (Harland \& Knight, 2001; Halvarsson Lundkvist \& Gustavsson, 2018; Pyka \& Janiszewski, 2016).

(3) The role of a broker as a network manager (Macchi et al., 2014; Idiagbon-Oke \& Oke, 2019; Leick \& Gretzinger, 2020; Srivastava, 2020). In networks composed of various actors, the task of brokers is to facilitate the flow of knowledge and information (Pyka \& Janiszewski, 2016).

A broker, as an intermediary of knowledge, connects an organisation with external elements. In networks composed of different actors (these can include, e.g., manufacturing or service companies, universities, private research organisations, affiliated research institutes, public research organisations), a broker's job is to facilitate the flow of knowledge and information. Brokers can facilitate access to new information or resources, knowledge transfer, and coordinate a network effort. Hence, knowledge brokers need to be embedded in research teams or institutions to positively influence the exchange of knowledge. The important term of brokerage is the essence of activities involving the integration of knowledge undertaken by brokers in the network. Entities operating in the network should be able to use the knowledge circulating internally. However, it is argued that there are differences in the results of companies due to asymmetry in access, assimilation and application of new knowledge (Dagnino et al., 2015; Janiszewski, 2019).
Often, many SMEs can only access external knowledge sources with the help of actors who are well connected to global knowledge sources so that they are able to translate information into a form that is useful for local organisations. The first reason why SMEs collaborate with knowledge brokers is that some companies may find it difficult to collaborate with others internationally. The second reason is that knowledge brokers can focus on enabling other organisations to establish and maintain relationships. They can also actively help in building lasting relationships.

Consequently, the emphasis is often placed on the role of knowledge brokers in the knowledge transfer process helping others to translate knowledge coming from the outside. Srivastava listed five different types of brokers, namely, a gatekeeper, a coordinator, a liaison, a representative, and a cosmopolitan broker (2020, p. 438).

The third reason is that companies should try and make their needs desirable for business partners. The services provided by knowledge transfer intermediaries should involve various mechanisms of cooperation with businesses, social institutions, governments and citizens. The critical remarks regarding the use of an external intermediary should also be underlined. "When a company outsources tasks related to innovation, it has big problems with implementing the proposals suggested by external consultants" (Trias de Bes \& Kotler, 2013, p. 5).

This article focuses on innovation brokers who operate internationally. Network brokers can be useful when SMEs lack direct contacts with business partners, resulting in fewer interactions, less knowledge sharing, and less trusted relationships (Leick \& Gretzinger, 2020).

Business networking, which is defined as "the participation of companies in many overlapping intercompany relationships and collaborative arrangements, actually supports companies in overcoming resource scarcity as it gives them access to new constellations of resources and improves the circulation of knowledge.

These network advantages can increase the innovativeness of enterprises and stimulate innovation processes" (Leick \& Gretzinger, 2020, p. 840). As part of the network, companies combine complementary resources, share information and collaborate to achieve common goals (Idiagbon-Oke \& Oke, 2019). The sum of knowledge acquired by companies is a key resource for achieving a competitive advantage (Crupi et al., 2020). 


\section{RESEARCH METHODS}

The article used the bibliometric method and a case study.

The bibliometric method is a general interdisciplinary tool employed by researchers from various scientific fields (Glänzel, 2003; Youngblood \& Lahti, 2018; Barkun, 2019). The scientific methods applicable in exact sciences were first proposed by de Solla Prince in 1965 (Boyack et al., 2005). Bibliometric methods involve two procedures: performance analysis and scientific mapping (Gaviria-Marin et al., 2019). The former aims to assess the outcomes of research and publications by scholars and institutions. The latter aims to reveal the dynamics and structure of selected scientific disciplines. Such information is of particular significance when a researcher reviews a specific line of research (Zupic \& Čater, 2015).

Different approaches exist to research based on bibliometric analysis. This article used the one presented by Gaviria-Marin et al. and others. It involves the following steps: (1) the choice of a research subject, (2) the bibliometric analysis of papers selected as the research object, (3) the analysis of the frequency of keywords indicated by the authors of the selected papers, and (4) the content analysis - a study of the links between keywords (Gaviria-Marin et al., 2019).

A number of techniques and software tools have been developed for scientific mapping (Cobo et al., 2011). The results are usually presented in the form of a map showing relationships among particular elements (Halicka, 2017; Szpilko, 2017; Siderska \& Jadaa, 2018; Winkowska et al., 2019). This study used the VOSviewer software, which creates representative and legible visualisations of the more complex networks (van Eck \& Waltman, 2007). The tool was specifically designed to construct and visualise bibliometric maps, with particular attention to the graphic representation of network clusters and widespread use of continuous bibliometric investigations (van Eck \& Waltman, 2010; Sweileh et al., 2016; Taşkin \& Aydinoglu, 2015). Grouping is based on modules, and clusters are created depending on the strength of association between nodes (Waltman et al., 2010).

The article applies the keyword co-occurrence analysis, which is a type of co-word analysis (Lis, 2020; $\mathrm{He}, 1999)$. This technique is classified as a scientific mapping method (Zupic \& Čater, 2015; Klincewicz et al., 2012). Analysis of keywords is an efficient method that allows examining the relationships between key terms and their evolution in time (Castriotta et al.,
2021). For this analysis, the bibliometric data were downloaded from the Scopus database, which is one of the leading databases indexing high-quality scholarly publications.

The experiences of the GoSmart BSR project served as the case study for the article. In this situation, the case study analysis was participatory. The project encountered problems with recruitment for the posts of international innovation brokers (IIBs) and with the development of essential competences for the realisation of the project. The solution addressed the following research questions:

(1) What general framework for measures within the network of cooperating project partners determines the development of international innovation brokers' competences?

(2) What substantive knowledge is indispensable for the effective realisation of measures in an international context?

(3) What skills must be in focus in terms of knowledge applied to solve problems and choose optimal solutions allowing to realise project objectives and enable teamwork in an international environment?

(4) What attitudes, understood as specific aptitudes, are relevant for the efficient work of brokers of innovation and SMEs internationalisation?

The purpose of the research conducted under the GoSmart BSR project was to identify the competences of international innovation brokers (IIBs). The research procedure was mainly targeted at constructing an original model of competences of IIBs responsible for supporting the SMEs sector in terms of internationalisation, smart specialisation and innovation. The study was qualitative.

Generally, qualitative study methods (normative methods) are employed when the investigated phenomena are difficult to represent quantitatively and when creative thinking is necessary (Kononiuk \& Magruk, 2008). Brainstorming is among the heuristic methods of creative problem-solving. The term was first used by Alex Osborn in 1942 (Casanovas et al., 2011; Putman \& Paulus, 2009). It is a creative and interactive method (Byron, 2012; Hilliges et al., 2007) involving teamwork, thus enabling interaction among participants and facilitating the rapid accumulation of numerous ideas for solving a posed problem (Baruah \& Paulus, 2019; Thompson, 2003; Paulus et al., 2011; Wang et al., 2010). Another advantage of the approach is that its participants are more committed to solving problems. In GoSmart BSR, brainstorming was aimed at finding out the opinions and expectations concern- 
ing the professional competences required of innovation brokers working in an international environment and proposing the ultimate model of innovation broker competences in an international context. Brainstorming was conducted among brokers, i.e., persons employed in this position in seven partner countries, and among coordinators of measures associated with the Transnational Innovation Brokerage System (TIBS). The research was conducted in 2019-2020. The work on creating the broker competence model was managed by one of the project partners, i.e., from Finland (the moderator of the brainstorming session). As the project partners were located in different countries, the talks were conducted online (via Internet and e-mail) and in-person during training workshops. A step-by-step team method of creative problemsolving was used along with a creative inductive thinking approach.

Before the brainstorming stage, three tasks were set, starting with (1) collecting multiple ideas - listing as many competences as possible. First, views were exchanged, then arguments and counterarguments were presented to generate a high number of suggestions and to initiate a debate among brokers and representatives of the project partners. (2) The second task consisted of identifying groups of ideas; the synergy of ideas allowed to combine them into groups. Next, another debate was held concerning the groups of competences and the range of their specific requirements (in the fields of knowledge, skills and attitudes). The overall proposal was debated again, which resulted in a draft version of the model of international innovation broker competences. In the preliminary version of the model, requirements for six groups of competences were formulated and described. (3) The third task was to develop the ultimate solution entitled Competence Mapping Checklist. The competences were described in an internal document, "TIBS Handbook", available for use by the brokers and project partners.

\section{RESEARCH RESULTS}

\subsection{GENERAL FRAMEWORK OF ACTION IN THE PARTNER NETWORK OF THE GOSMART BSR PROJECT}

Presented below is the general framework of the GoSmart BSR project, which determines the professional development of the competences expected of international innovation brokers:
(1) The project's primary objective is to support SMEs in internationalisation and innovation efforts. Internationalisation is considered an opportunity for SMEs to encourage action in foreign markets and to raise the level of their innovation performance. According to the updated Uppsala model, it was assumed that knowledge creation and exchange and the project stakeholder interactions were the basis of this process.

(2) Focusing on promising areas for the prospective development of the regional economy and smart specialisations. SMEs operating in the specialisation area united into a cooperation network for the key project stakeholders due to a greater likelihood of success and better business prospects.

(3) Using a broad definition of innovation, based on the terminology from the Oslo Manual, published by the OECD. Innovations were divided according to subject criteria, considering significant technological and other changes. Product, process, organisational and marketing innovations were distinguished.

(4) Using the "open innovation" concept proposed by Chesbrough as a way to implement innovation processes in SMEs. The basic assumption of open innovation is cooperation with various subjects, gaining and adapting knowledge from external sources with a view to raising the efficiency of creating and implementing innovative solutions (Bogers et al., 2018). It was assumed that to streamline their activities and technologies, enterprises could and should rely on knowledge flows, external and internal ideas in their innovative processes, and internal and external paths of launching innovations in the market.

It is important to focus on constructing an environment that is conducive to the development of internationalisation and potential innovations in SMEs, based on the quadruple helix model. Such a network means participation and cooperation of key actors from the field of science and research, enterprises, and central and regional governments for the sake of creating Joint Transnational Smart Strategies (JTSS).

International innovation brokers play a key part in the network of participants. The brokerage system consists of brokers from the Baltic Sea Region.

Internationalisation processes occurring in SMEs have a positive effect of creating and transferring knowledge within a network of cooperating subjects. Previous research confirmed that innovations open opportunities to operate beyond country borders and not the other way around, chiefly in the case of product innovations. The GoSmart BSR project fills a gap 
by assuming that internationalisation might result in implementing innovations in various areas thanks to the experience gained in foreign markets. This requires, among other things, having a team of brokers with strong individual competences, which add up to team competences in a project. Without the professional expertise of brokers, it is not possible to create knowledge resources, integrate large amounts of information, diagnose these resources or use them to unite groups of enterprises into regional value chains, form groups of businesses that develop joint transnational strategies of smart specialisations and, consequently, obtain an added value of the entire project.

The task of international innovation brokers representing project partners is to implement the TIBS. It is defined as a network-based support system to assist groups of SMEs in defining and implementing their Joint Transnational Smart Strategy (JTSS) across partner regions and beyond. The TIBS service encompasses three groups of activities. First, recruitment, pre-treatment and assessment of the client; second, matching partners; and third, elaboration of transnational business models for a group of SMEs. The range of activities undertaken by international innovation brokers includes:

- Identifying SMEs sector companies in target regions that are willing to cooperate in the project and have high internationalisation potential;

- Building cooperation networks and relationships among brokers representing specific project partners, between brokers and SMEs and other subjects from the business milieu (other business support organisations at a national and regional level), i.e., the stakeholders of internationalisation and innovation development;

- Establishing contacts with SMEs to initiate internationalisation processes through joint broker efforts to develop internationalisation models and, under this framework, potential innovations and cooperation aimed at concluding agreements between SMEs from partner regions.

The TIBS, apart from methods and tools (technology or "content"), required skilled and capable staff directly engaged in service delivery and dealing directly with final beneficiaries. These functions were performed by innovation and internationalisation brokers (IIBs) who were supported methodologically by the project and institutionally by the GoSmart partner organisations. TIBS methods and tools, which defined the process of service delivery to beneficiaries (SMEs and their innovation and internationalisation partners), covered all the steps of the development and care of Joint Transnational Smart Strategies by trans-regional groups of SMEs. IIBs were competent in the field and willing to work with business and $\mathrm{R} \& \mathrm{D}$ actors.

\subsection{ATTRIBUTES OF INNOVATION BROKERS: A BIBLIOMETRIC ANALYSIS}

One of the purposes of this article is to identify and classify the attributes and competences of innovation brokers as described in the scholarly literature from the field of "Business, Management and Accounting". The study intends to present a review of the subject's research evolution and describe structures typical of the considered topic. The results allow identifying the main areas that have been investigated heretofore and indicating literature gaps, offering an opportunity to explore the topic more broadly in the future. The study is explorative. It was performed using bibliometric analysis and the VOSviewer software (www.vosviewer.com, 14.10.2021). The references were drawn from the Scopus database (www. scopus.com, 12.10.2021).

For the purposes of the study, keywords "innovation" and "broker" were used (also when they occurred in titles and abstracts). In total, 537 publications matched the filters. Retrospection of the subject scope begins in 1980. However, researchers' interest started to increase at the beginning of the year 2000. As Fig. 1 below shows, between 1980 and 1999, the number of publications ranged from 0 to 6 . In the years 2000 2004, it was 5-9; between 2005 and 2014, it rose from 12 to 42 annually; in 2015-2020, from 35 to 44 documents were published every year.

As for the subject areas (Fig. 2), the documents concerned: "Business, Management and Accounting" (20\%), "Social Sciences" (17.1\%), "Computer Science" (11.7\%), "Engineering" (10.4\%), "Medicine" (6.4 \%), "Economics, Econometrics and Finance" (5.7 \%), "Decision Sciences" (5.6 \%), "Environmental Science" (5.4\%), "Agricultural and Biological Sciences" (4.0\%), "Arts and Humanities" (3.7 \%), and "Other" (10.1\%).

The largest number of publications on the topic of innovation brokers is issued by the United States (111 publications), followed by the United Kingdom (77 publications) and Italy (45 publications). In general, the top ten countries represent Europe plus Canada, Australia and China.

To streamline the study results, the subject area was restricted to "Business, Management and Accounting", and, as a result, 196 publications that 


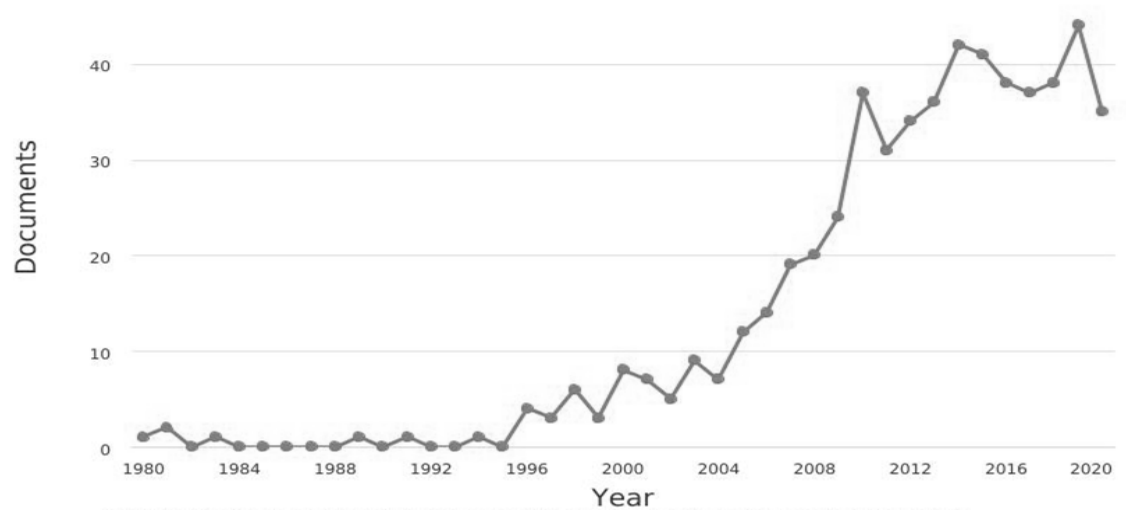

Fig. 1. Distribution of the documents by publication year Source: Elaborated by the authors based on www.scopus.com (12.10.2021).

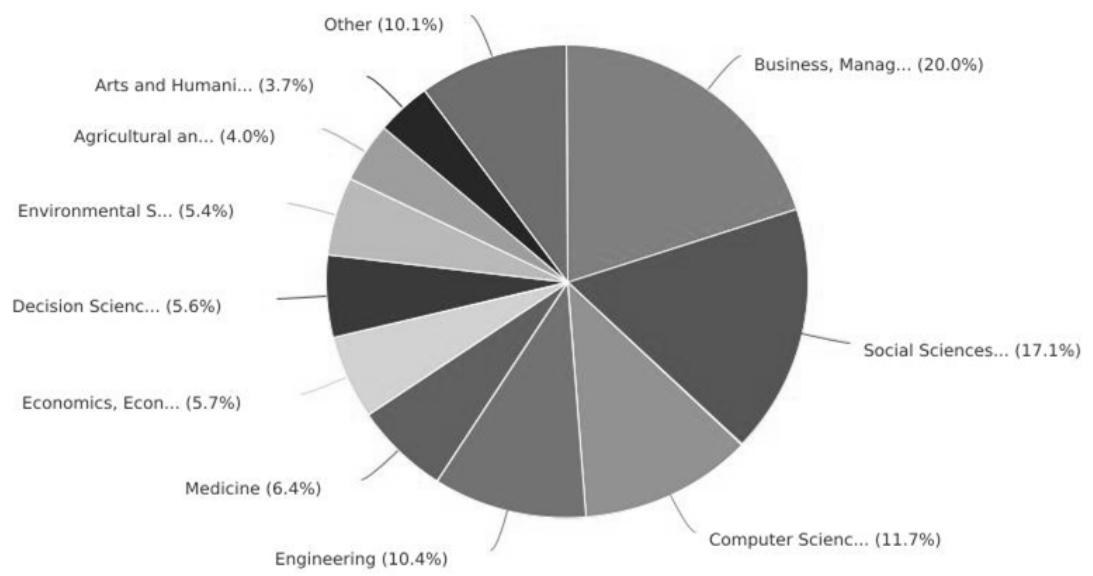

Fig. 2. Distribution of the documents by subject area

Source: Elaborated by the authors based on www.scopus.com (12.10.2021).

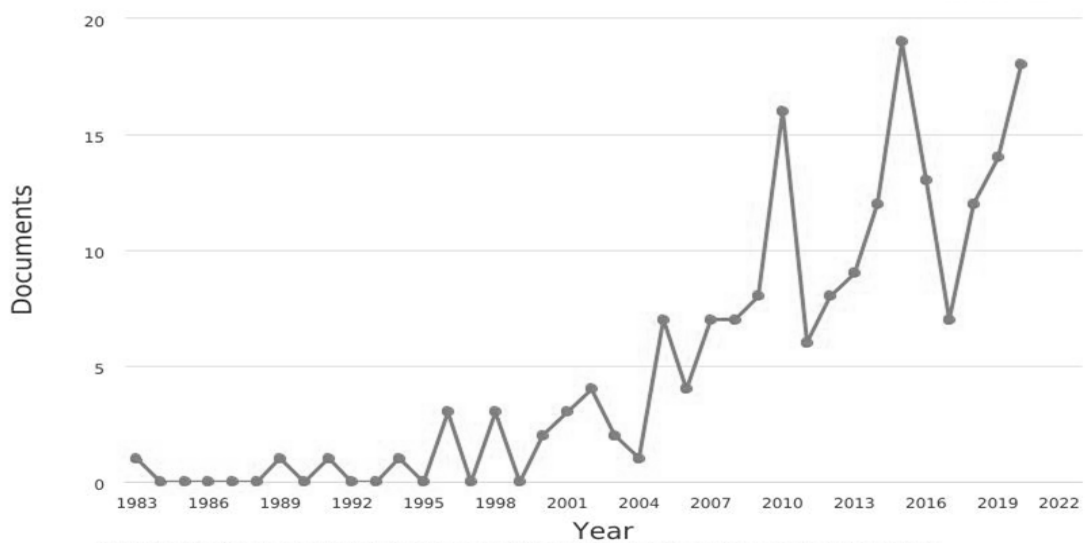

Fig. 3. Distribution of documents in the subject area "Business, Management and Accounting" by publication year Source: Elaborated by the authors based on www.scopus.com (12.10.2021). 
matched the filter were obtained. According to Fig. 3, the first references to the topic of innovation brokers in the subject area "Business, Management and Accounting" appeared in 1983. In the years 1983-2001, the number of publications ranged from 0 to 3 , and between 2002 and 2020, from 1 to 19 annually.

In the analysed area, the Scopus database contains publications about 37 countries/territories of origin, plus undefined, concerning the topic of innovation brokers. According to the figure below (Fig. 4), the largest number of publications is connected with the
United States (42 publications), followed by Italy ( 26 publications), the United Kingdom (23 publications), and Germany (14 publications). In general, the top ten countries represent Europe, Canada and China.

For further analysis with the use VOSviewer, the option of co-occurrence of keywords was selected. Overall, 1044 keywords were generated. A minimum occurrence of three was chosen, as a result of which the number of keywords was narrowed down to 85 . Next, filtration of keywords was performed to sort the information obtained from Scopus.

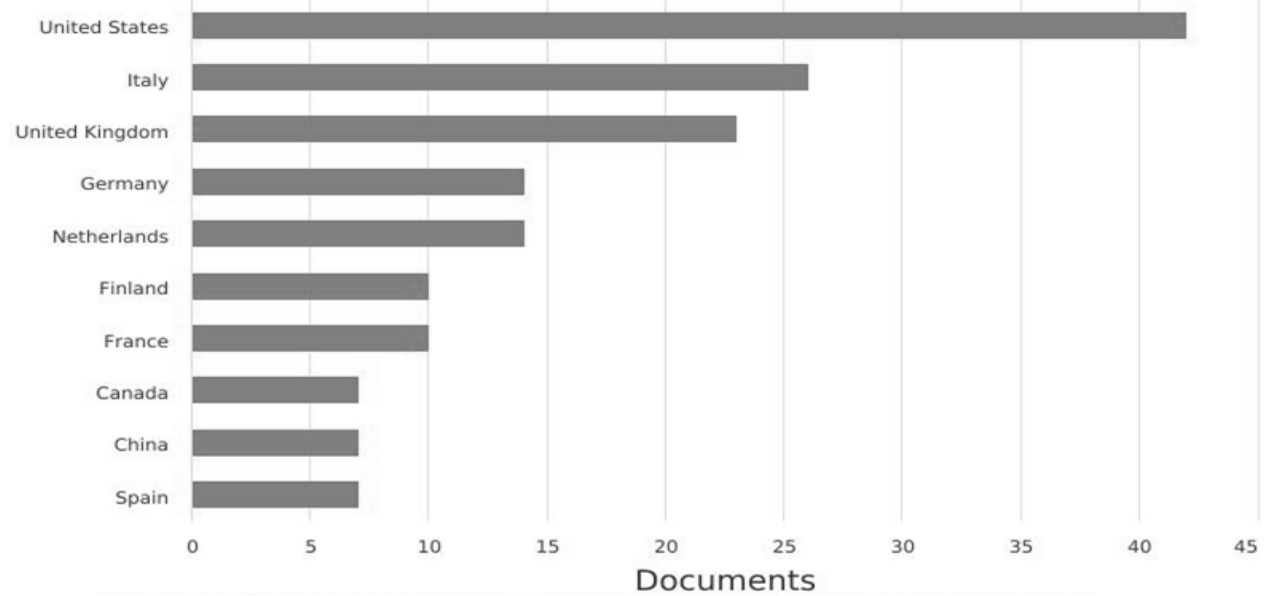

Fig. 4. Distribution of documents in the subject area "Business, Management and Accounting" by country of origin Source: Elaborated by the authors based on www.scopus.com (12.10.2021).

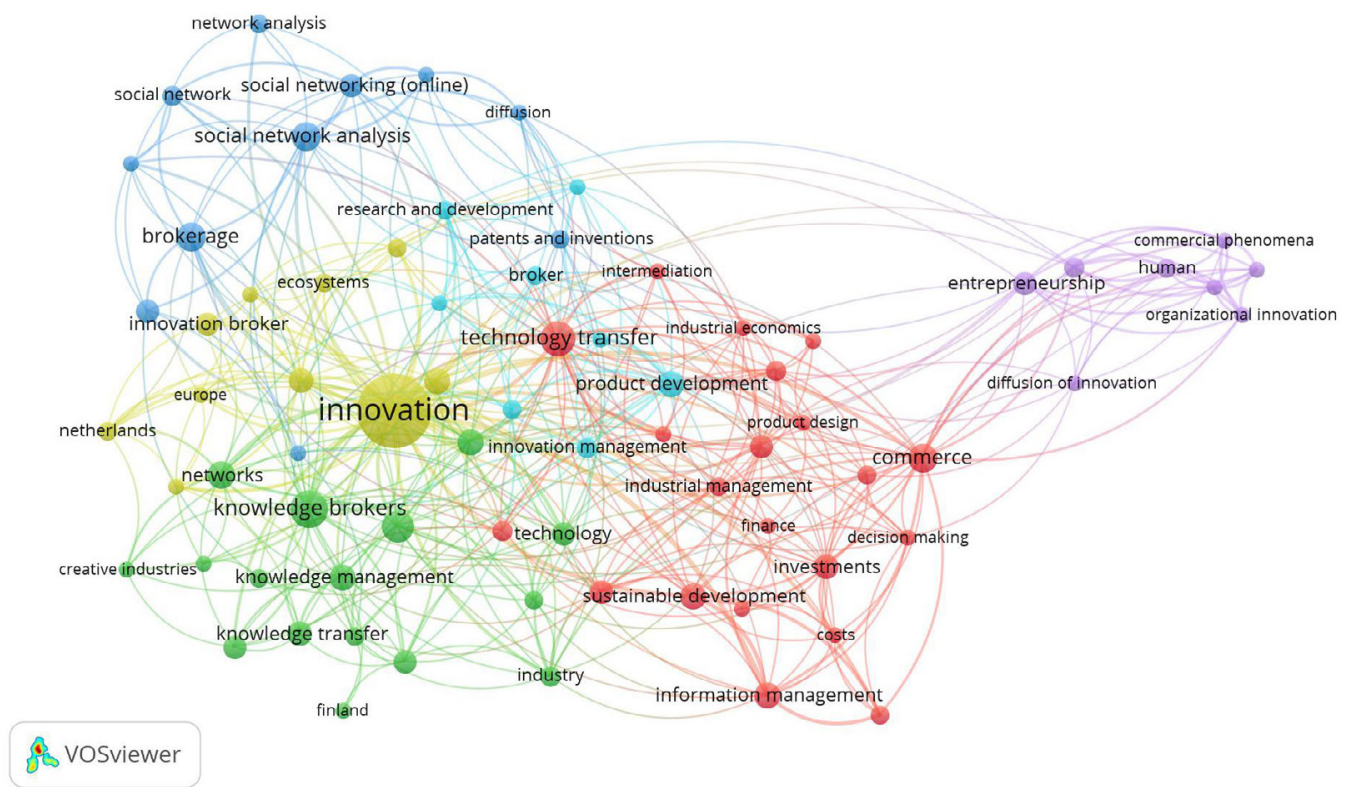

* The larger the circles, the higher the occurrence frequency.

Fig. 5. Keyword co-occurrence mapping for "innovation" and "broker" topic

Source: Elaborated by the authors based on Scopus, using VOS-viewer software www.vosviewer.com (14.10.2021). 
As the figure (Fig. 5) above demonstrates, the most frequently occurring keywords included: innovation, knowledge brokers, technology transfer, commerce, brokerage and social network analysis. Six clusters were identified, four of them interrelated, one slightly peripheral.

Mapping of keywords shows that an innovation broker can have certain attributes. According to VOSviewer analysis (Table 1), six clusters can be formed with a total of 85 items. The first cluster contains 21 items, the second -16 items, the third -11 items, the fourth -10 items, the fifth -8 items, the sixth -8 items.

There are differences and similarities across the clusters. It can be assumed that a key difference regarding Cluster 1 is that it comprises issues from several categories: competition, investment, finances, technology and trade. It is also related to social and economic effects and sustainable development. Cluster 2 is thematically oriented towards co-operation, knowledge transfer (knowledge brokers knowledge management, knowledge sharing) and innovation (innovation networks, open innovations, innovation process). Cluster 3 focuses on social networking and also involves attributes of dissemination and brokerage of patents and inventions. Cluster 4 is largely oriented towards brokers/intermediaries of innovation. Cluster 5 is connected with issues regarding R\&D and the development of products. Cluster 6 is centred around diverse issues, e.g., people, organisations or dissemination of innovations.
Analysis of scientific mapping reveals that research concentrates on innovation brokers, innovation systems, social networks and knowledge transfer, which is consistent with the assumptions of the GoSmart BSR project.

In view of the topic of this study and the outcomes of the bibliometric analysis obtained for "innovation" and "broker", in the next stage, the scope of the analysis was widened and encompassed "innovation", "broker", and "competences". As a result, 21 publications from all the research areas matched the filters. For further study using VOSviewer, the option of keyword co-occurrence was selected. A total of 247 words was generated. A minimum occurrence of three was chosen, narrowing down the number of keywords to 12 (Fig. 6).

Two related clusters were identified (Table 2). The first contains seven items, the second - five items.

The attributes contained in both clusters fall within GoSmart BSR assumptions regarding innovation, knowledge management, competence brokering and regional development.

Summing up the conducted bibliometric analysis, it should be pointed out that the main identified areas published in Scopus have so far been consistent with the assumptions of the project, which is the subject case examined by this study. On the other hand, gaps can be noticed in previously published articles concerning the competences of international innovation brokers. First and foremost, the project broadens the concept of broker competences, going beyond their

Tab. 1. Keywords clusters

\begin{tabular}{|c|c|c|}
\hline $\begin{array}{l}\text { CLUSTER } \\
\text { NUMBER }\end{array}$ & $\begin{array}{l}\text { NUMBER OF } \\
\text { ITEMS }\end{array}$ & KEY WORDS \\
\hline $\begin{array}{c}1 \\
\text { (red) }\end{array}$ & 21 & $\begin{array}{l}\text { commerce, competition, costs, decision making, economic and social effects, economics, electron- } \\
\text { ic commerce, finance, financial innovation, industrial economics, industrial management, infor- } \\
\text { mation management, innovations, intermediation, investments, marketing, product design, SMEs, } \\
\text { sustainable development, technology brokers, technology transfer }\end{array}$ \\
\hline $\begin{array}{l}2 \\
\text { (green) }\end{array}$ & 16 & $\begin{array}{l}\text { collaboration, creative industries, Finland, industry, innovation network, innovation process, inter- } \\
\text { mediaries, knowledge broker, knowledge brokering, knowledge brokers, knowledge management, } \\
\text { knowledge sharing, knowledge transfer, networks, open innovation, technology }\end{array}$ \\
\hline $\begin{array}{c}3 \\
\text { (blue) }\end{array}$ & 11 & $\begin{array}{l}\text { brokerage, diffusion, industrial performance, innovation networks, network analysis, patents and } \\
\text { inventions, social network, social network analysis, social networking (online), social networks, so- } \\
\text { cial sciences computing }\end{array}$ \\
\hline $\begin{array}{l}4 \\
\text { (yellow) }\end{array}$ & 10 & $\begin{array}{l}\text { ecosystems, Europe, innovation, innovation broker, innovation brokers, innovation intermediaries, } \\
\text { innovation system, Netherlands, technological change, technological forecasting }\end{array}$ \\
\hline $\begin{array}{l}5 \\
\text { (light blue) }\end{array}$ & 8 & $\begin{array}{l}\text { broker, information dissemination, innovation management, new product development, product } \\
\text { development, project management, research and development, research and development man- } \\
\text { agement }\end{array}$ \\
\hline $\begin{array}{c}6 \\
\text { (violet) }\end{array}$ & 8 & $\begin{array}{l}\text { commercial phenomena, diffusion of innovation, entrepreneurship, human, organization, organi- } \\
\text { zation and management, organizational innovation, United States }\end{array}$ \\
\hline
\end{tabular}

Source: Elaborated by the authors based on www.scopus.com (14.10.2021). 


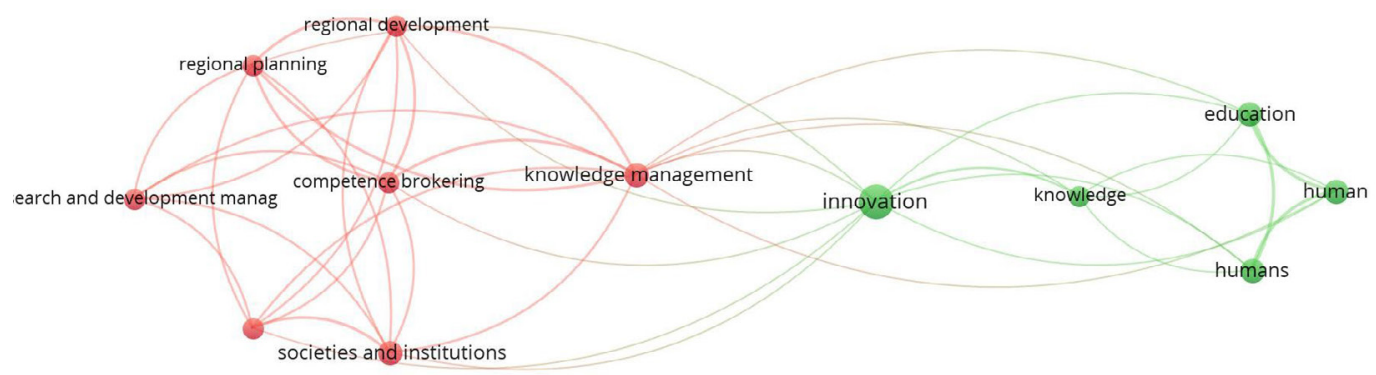

vosviewer

* The larger the circles, the higher the occurrence frequency.

Fig. 6. Keyword co-occurrence mapping for "innovation", "broker", and "competences"

Source: Elaborated by the authors based on Scopus, using VOS-viewer software www.vosviewer.com (14.10.2021).

Tab. 2. Keywords clusters

\begin{tabular}{|c|c|c|}
\hline $\begin{array}{c}\text { CLUSTER NUM- } \\
\text { BER }\end{array}$ & $\begin{array}{c}\text { NUMBER OF } \\
\text { ITEMS }\end{array}$ & KEY wORDS \\
\hline $\begin{array}{c}1 \\
\text { (red) }\end{array}$ & 7 & $\begin{array}{c}\text { competence brokering, industrial research, knowledge management, regional development, re- } \\
\text { gional planning, research and development management, societies and institutions }\end{array}$ \\
\hline $\begin{array}{c}2 \\
\text { (green) }\end{array}$ & 5 & education, human, humans, innovation, knowledge \\
\hline
\end{tabular}

Source: Elaborated by the authors based on www.scopus.com (14.10.2021).

knowledge and accounting also for their skills and attitudes. Moreover, the activities undertaken by the brokers of the project are of international character, which in the future may make it possible to apply the identified competences also in other regions beyond the Baltic Sea Region.

\subsection{COMPETENCES OF INTERNATIONAL INNO- VATION BROKERS - MODEL APPROACH AND DISCUSSION}

Competence is having knowledge and experience in a certain field, enabling the proper performance of duties and making the right decisions (Lenart-Gansiniec, 2018). The partners of the GoSmart BSR project clarified the general conditions that were considered when recruiting for a broker position in each partner country. The starting assumptions are general and specific knowledge gained through work experience at enterprises from the SMEs sector. The central part of the concept is the support for the internationalisa- tion of SMEs in participating regions. In the GoSmart project, the business support system, TIBS, has been developed and tested, supporting SMEs' internationalisation process and initiating collaboration between companies primarily within the GoSmart regions.

The framework for broker activities is the area of project implementation that defines geographic markets and focuses efforts on specific areas of smart specialisation. The process of recruitment and competence development is presented in Fig. 7.

The project partners committed themselves to ensuring the appropriate competences of the employed brokers. It was considered necessary to conduct an intensive international training programme financed by the project. The adjustment and extension of the competences of the employed innovation brokers considered such factors as:

- the scope of duties related to the provision of TIBS services. The basic purpose of the services is to undertake activities in foreign markets and to focus on innovation in the SME community; 


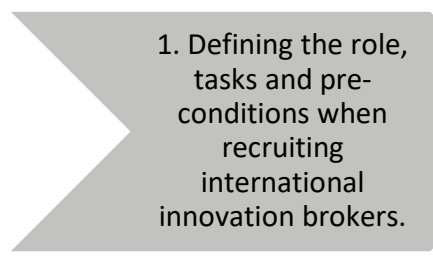

Defining the role, tasks and preconditions when recruiting international innovation brokers.

\section{The recruitment of international innovation brokers in partner countries of the project.}

3. The participation of international

innovation brokers in the training programme for competence development.

Fig. 7. Illustration of the international innovation broker process

- the implementation of an intensive capacity building programme (CBP) in practice;

- the possibility of changes in the competencebuilding programme depending on the needs reported by brokers in terms of knowledge and skills as well as the implementation of the assumed project objectives.

The intensive formal international training programme was composed of internal and external training with innovation promotion institutions, coaching from external project experts to the host organisation and representatives of other project partners and short-term external placements. The recruitment of brokers was completed in the 3 rd Period of the project, and the formal international training in the 4th and 5th Periods. All international innovation brokers (IIBs) completed an intensive training programme composed of internal training within representatives of project partners and external training with innovation promotion institutions; they received coaching on the job and short placement abroad within the project partnership. IIBs participated in three dedicated training events in Vilnius, Riga, and Aabenraa. CBP Part 1-3 focused on the brokers' role, tasks, tools, competences and insights while interacting with SMEs on innovation and internationalisation processes and strategies. Further, the CBP focused on how to make brokers cooperate efficiently. IIBs met to build their capacity in supporting SMEs towards their internationalisation and innovation and to train in processes, tools and cooperation between brokers, making the TIBS's services to SMEs effective. CBP developed areas of broker competence in the network, practical training working with a number of business cases presented by project partners and by external consultants and company visits.

The brokers are specialised in supporting SMEs seeking transnational cooperation within common specialised sectors and identifying potential innovations. The competences are divided into six areas:

- $\quad$ TIBS specific knowledge;

- Innovation-related competences;
- Internationalisation-related competences;

- SME-consulting competences;

- Communication skills;

- Attitudes, professional experiences, and formal competences.

A list of IIBs key competences is presented in Table 3. The competences have been described in the internal document of the TIBS handbook to be used by brokers and project partners. When developing the competence model, the aim was to ensure utilitarian value, which, on the one hand, required the specification of the indicated competence groups and, on the other hand, was limited by the need to embed competences in the assumptions and objectives of the project. The proposed model of competences of international innovation brokers presented in the project may be supplemented with further groups of competences and thus should become a contribution to further discussion and modification.

A graphical overview of the competence areas of international innovation brokers is presented in Fig. 8.

The presented model is a synthesis of previous experiences in the area of formulating competences of international innovation brokers. The model considers five groups of factors that are desirable and can be developed within an organisation.

In addition to the above-mentioned competences in the areas of knowledge, skills and attitudes, in practice, goal orientation, loyalty to the project, social responsibility and the ability to work in an international team were also important. TIBS assumes building a business model of SMEs interested in creating innovations in the international dimension through innovation brokers. The synthesis and integration of dispersed knowledge and skills in the field of its application and broker attitudes lead to discovering opportunities for establishing beneficial cooperation of SMEs in the Baltic Sea Region and initiating joint transnational smart specialisation strategies (JTSS). Interactions and building relationships between brokers and SMEs, and other stakeholders are also of utmost importance. The cooperation of brokers from 
Tab. 3. Professional experiences and formal competences - the Competence Checklist according to the experience of the GoSmart BSR project

\begin{tabular}{|c|c|}
\hline GROUP & DESCRIPTION \\
OF COMPETENCES & D
\end{tabular}

Knowledge and skills required in connection with the implementation of the project (regarding the assumptions and expected effects of the GoSmart BSR project)

\begin{tabular}{|c|c|}
\hline \multirow{3}{*}{$\begin{array}{l}\text { TIBS specific } \\
\text { knowledge }\end{array}$} & - Understanding the TIBS value propositions \\
\hline & - Knowledge of the TIBS delivery process \\
\hline & - Excellence in applying TIBS tools \\
\hline \multicolumn{2}{|r|}{ Knowledge and skills related to internationalisation and innovation } \\
\hline \multirow{5}{*}{$\begin{array}{l}\text { Innovation related } \\
\text { competences }\end{array}$} & - Knowledge of S3 concept and its application in own region/country \\
\hline & - Innovation evaluation skills and techniques \\
\hline & - Innovation process skills and techniques \\
\hline & - Innovation project management skills and techniques \\
\hline & $\begin{array}{l}\text { - Knowledge of regional/national and international supporting tools and funding instruments for } \\
\text { innovations }\end{array}$ \\
\hline \multirow{4}{*}{$\begin{array}{l}\text { Internationalisation } \\
\text { related competences }\end{array}$} & - $\quad$ Basic knowledge about S3 of TIBS partner regions, regional strengths, main clusters, etc. \\
\hline & - Knowledge of internationalisation models, strategies and benefits \\
\hline & $\begin{array}{l}\text { - Knowledge of relevant frameworks for evaluating SME readiness to internationalisation, selecting } \\
\text { right markets, operational mode, partner etc. }\end{array}$ \\
\hline & $\begin{array}{l}\text { - Knowledge of regional/national and international supporting tools and funding instruments for } \\
\text { internationalisation of SMEs }\end{array}$ \\
\hline
\end{tabular}

Knowledge and skills in the areas of operation of an enterprise and its sectoral environment, planning and forecasting the effects of undertaken actions

\begin{tabular}{|c|c|}
\hline \multirow{11}{*}{$\begin{array}{l}\text { SME consulting } \\
\text { competences }\end{array}$} & - Knowledge of the regional business environment, especially SMEs \\
\hline & - Wide personal contact network in the local business community \\
\hline & $\begin{array}{l}\text { - Wide knowledge across different industries and Trans-S3 specific knowledge domains, sectors/sub- } \\
\text { sectors, technologies and themes }\end{array}$ \\
\hline & - Knowledge of regional/national and international supporting tools and funding instruments for SMEs \\
\hline & $\begin{array}{l}\text { - Knowledge of relevant frameworks to evaluate company's current processes and identify company's } \\
\text { needs quickly }\end{array}$ \\
\hline & - Value chain analysis skills and techniques \\
\hline & - Financial analysis skills and techniques \\
\hline & - Problem-solving skills and techniques \\
\hline & - Strategic planning tools and techniques \\
\hline & - Action planning skills and techniques \\
\hline & - Fluency in customer service \\
\hline \multicolumn{2}{|r|}{ Skills and attitudes of building interpersonal bonds } \\
\hline \multirow{8}{*}{$\begin{array}{l}\text { Communication skills } \\
\text { in an international } \\
\text { network }\end{array}$} & - Fluency in written and spoken English in addition to one's local languages \\
\hline & - Active contacting skills and drive makers \\
\hline & - Opening doors to business decision \\
\hline & - Assertiveness in demanding business situations \\
\hline & - $\quad$ Strong networking skills \\
\hline & - Negotiation skills \\
\hline & $\begin{array}{l}\text { - Fluency in producing documents, presentations and reports by using modern office information } \\
\text { systems and tools }\end{array}$ \\
\hline & - Social media skills to promote TIBS and networks \\
\hline & Attitudes and skills of professional operation \\
\hline
\end{tabular}




\begin{tabular}{|c|c|}
\hline \multirow{11}{*}{$\begin{array}{l}\text { Professional } \\
\text { qualities and formal } \\
\text { competences }\end{array}$} & - Proactivity and self-steered working skills \\
\hline & - Flexibility to changing situations \\
\hline & - Readiness to travel and co-operate in different working cultures \\
\hline & - Openness to new approaches, tools and techniques \\
\hline & - Drive for self-education and professional growth \\
\hline & - Years of higher education in Management, Business or Technology \\
\hline & - Working experience in general \\
\hline & - Working experience in SME sector or business consulting \\
\hline & - Practical customer service experience \\
\hline & - Working experience in multicultural teams \\
\hline & - Experience in applying for EU support programmes \\
\hline
\end{tabular}

Source: Elaborated by the authors based on TIBS Handbook.

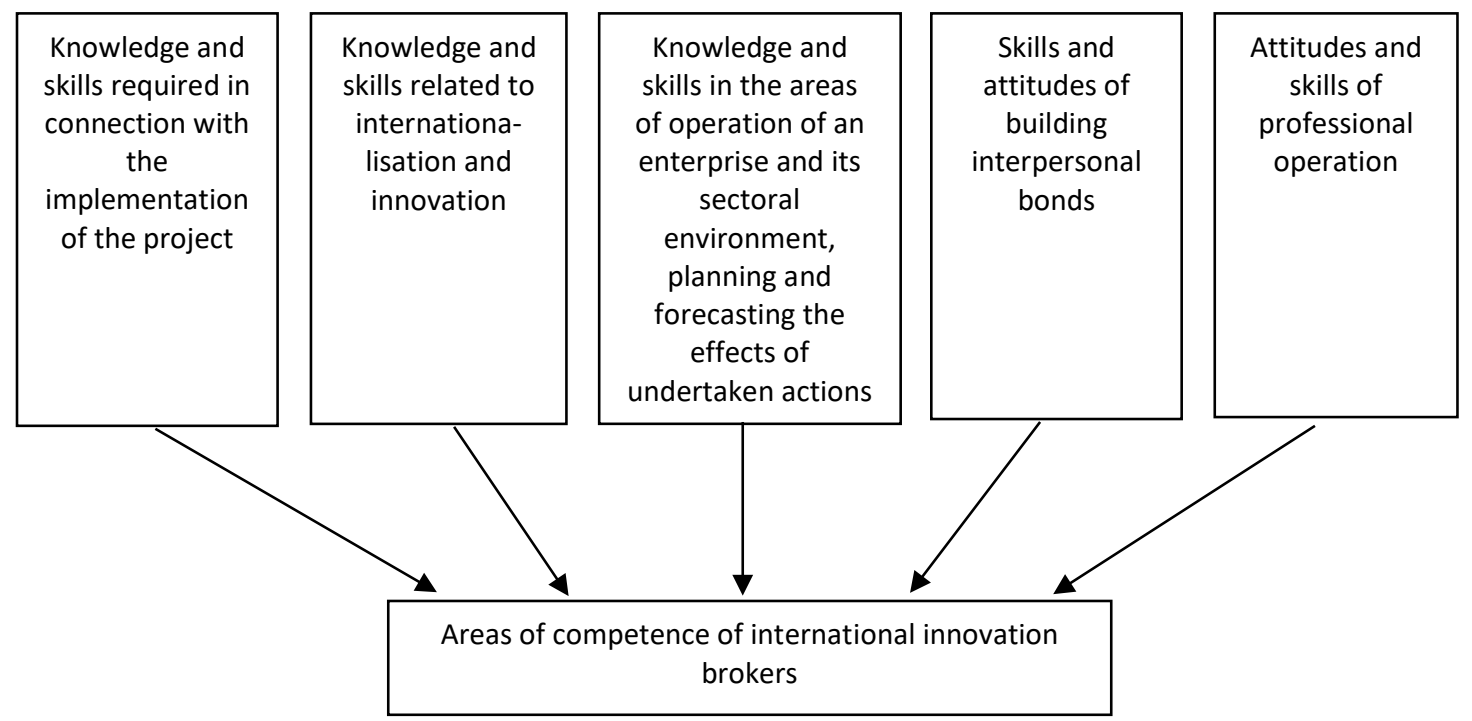

Fig. 8. Areas of competence of international innovation brokers

different backgrounds and traditions, bringing different experiences and their focus on the objectives of the project, favours the initiation of internationalisation and innovation processes of SMEs. It should also be emphasised that the broker activities allow shortening the time needed for identification and communication of partners, as well as reducing the workload of SMEs on acquiring new markets.

The implementation of TIBS services in practice and the identification of the necessary competences and their development during the project, as well as building cooperation between brokers from the area of selected Baltic Sea Region countries, contributed to the following effects:

- A database of 998 potential beneficiaries interested in internationalisation, including SMEs, clusters, $R \& D$ units, organisations supporting business from partner regions;

- 171 offers to develop international cooperation in the SME sector;

- An association of 104 foreign partners, and in the case of 44 entities, defining the business model of internationalisation and innovation;

- 22 SME groups developing JTSS.

\section{DISCUSSION OF THE RESULTS}

In the relevant literature on management and quality, competences are considered from the perspective of an individual (or teams) or entire organisations (Bergenhenegouwen et al., 2020). The first 
category consists of individual competences of particular employees. Although the knowledge and skills of employees can be created in an organisation, it is much more difficult to instil certain values and standards (Sudolska, 2006). These competencies include knowledge, skills, values, standards, motives, work ethic, enthusiasm and self-image. The second category includes competences of an organisation, understood as the ability to use its material and non-material resources, the ability to use them in processes in a way that helps to achieve the goals of an organisation. According to Penrose, competences constitute a central category of the Resource-Based View of the firm (Sudolska, 2006). In this approach, competences are an element of intangible resources. They are understood as the company's ability to use its resources. Built on the basis of the organisation's resources, they are the main source of its competitive advantage. The diagnosis of competencies of both individual employees and organisational competences is a permanent element of competency management (Moczydłowska \& Serafin, 2016).

As part of the GoSmart BSR project, brokers form an international team, i.e., a group of people cooperating with each other to achieve a common goal. This goal is to raise the level of internationalisation and innovation of SMEs in the Baltic Sea Region. The brokers, as knowledge intermediaries in this process, provide SMEs with professional services and the necessary substantive support (information, consultation, advisory). International innovation brokers should have specific competencies when performing the tasks carried out in the project. The ventures supporting the development of their competences were provided by the project partners through the implementation of the Capacity Building Programme.

Despite the fact that competences are an important element of professional human development, there is no clear-cut understanding of this concept. Most often, competences are a combination of knowledge, skills and values of a given person, necessary for particular job positions. There are two trends in defining this concept in the literature (SzczepańskaWoszczyna, 2016). The first is the definitions linking competences directly with the person they concern, defining the scope of knowledge and skills, identifying them with a set of behaviours, abilities, personality traits as parameters that differentiate individuals from one another. The second trend consists of definitions referring to the performed work or the position held and treating competences as the performance of a function in an organisation, which results in specific work outcomes. Contemporary perception of competences requires a holistic approach. The holistic approach adopted in the GoSmart BSR project is consistent with both the behavioural trend and the functional understanding of competences.

By convention, competence is a combination of knowledge, plus skill, plus awareness or attitude (Dingle, 1995; Loufrani-Fedida \& Aldebert, 2021). According to Filipowicz (2016, p. 46), "competences are dispositions in the field of knowledge, skills and attitudes that enable the performance of professional tasks at an appropriate level". "For a team to be competent, its members must be competent" (Tidd \& Bessant, 2013, p. 190). The individual competences of innovation brokers consist of knowledge, skills and attitudes (Fig. 9). The combination of these elements determines the effective implementation of professional tasks. They also serve to achieve the goals of the organisation. Specific skills and knowledge are the so-called hard competences. Knowledge (general, acquired and accumulated from experiences related to professional work inside and outside the project) creates the basis for the implementation of various activities. Skills are repeatable models of activities; they refer to practical proficiency in carrying out specific tasks to introduce SMEs to foreign markets and to develop innovation in various areas. Skills depend on the creation, exchange and use of knowledge to solve problems creatively.

These competence elements undergo a transformation. Each of the brokers, in the course of training, acquires new substantive knowledge that directly relates to the task being performed and conditions, and at the same time enables further development of skills (teaches task behaviour, performing tasks). Interpersonal skills are also important, being vital in shaping relations between project stakeholders. Another element of competencies are attitudes that are equated with personality traits, specific values required from the broker, which may be conducive to achieving project goals. Attitudes that create the socalled soft competences are often mentioned and presented in the form of character traits and personality traits, such as, e.g., creativity, responsibility, independence, recognising one's strengths and weaknesses, high motivation, resistance to stress. The term "soft skills" denotes the mental skills of an individual and their ability to cope with social situations, necessary for effective and efficient interaction (Robotham \& Jubb, 1996). These features can influence the professional performance of brokers. Developing soft skills is not easy. However, their activation in the form 


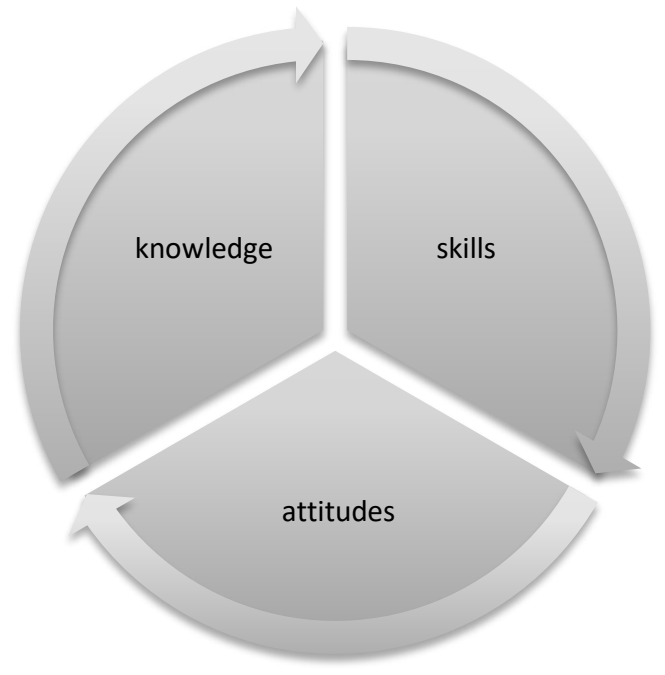

Fig. 9. Components of competences of innovation brokers

of specific, observable and desired actions of brokers depends on the rights granted under the project and working conditions, with particular emphasis on the role of an incentive system and the related organisational culture (Moczydłowska, 2008; Szydło, 2018; Szydło \& Grześ-Bukłaho, 2020).

The synthetic model of competences for international innovation brokers proposed by the authors adopts a holistic approach to defining competences. This model has the attribute of practicality and universality, i.e., the possibility of being used in various organisations working for the internationalisation and innovation of SMEs. This model is based on the following assumptions:

- The level of individual competences depends not only on the knowledge and skills but also on the broker attitudes (personality traits of brokers, predispositions, or their cognitive abilities); hence, the model considers such components as knowledge (mainly procedural "know-how"), skills (the ability to implement assumed behaviour patterns, ensuring the achievement of goals or results) and attitudes (willingness to take specific actions and use knowledge).

- The model assumes that due to the support of the organisation, individual competences contribute to the creation of competencies at the level of the entire organisation and the implementation of tasks in a manner consistent with the standards required for the provision of intermediation services and in accordance with the organisation's goal. Hence, the basis is the assumption that support from the organisation in their develop- ment has a positive effect on the level of broker tasks. Broker competences are deeply embedded in the method of management and are supported by the organisation (open culture, promoting the participation of all brokers in the creative process, promoting cooperation, exchange of knowledge, experiences); the relationship between competences and the level of task performance seems natural.

- The model considers the knowledge and skills grouped into four categories in the competence structure, which can be developed with the help of the organisation and by cooperation with other brokers. In addition, it includes elements of personality traits and broker attitudes that affect the overall quality of the work performed, which makes them desirable in the context of supporting the internationalisation and implementation of innovation in the SME sector.

- The input competences are primarily general knowledge and knowledge of the specificity of the business and experience in working with enterprises from the SMEs sector (knowledge and practical skills), as well as specific employee attributes. They represent a specific potential that the organisation then develops.

- The output includes benefits, effects, i.e., something valuable for stakeholders from the perspective of a broker (professional development), the organisation (achieving the assumed indicators, building relationships), and beneficiaries (SMEs - the impact on internationalisation and innovation). 


\section{Competences at the entrance}

Assumptions: general knowledge and specific knowledge gained through work experience in working with enterprises from the SMEs sector

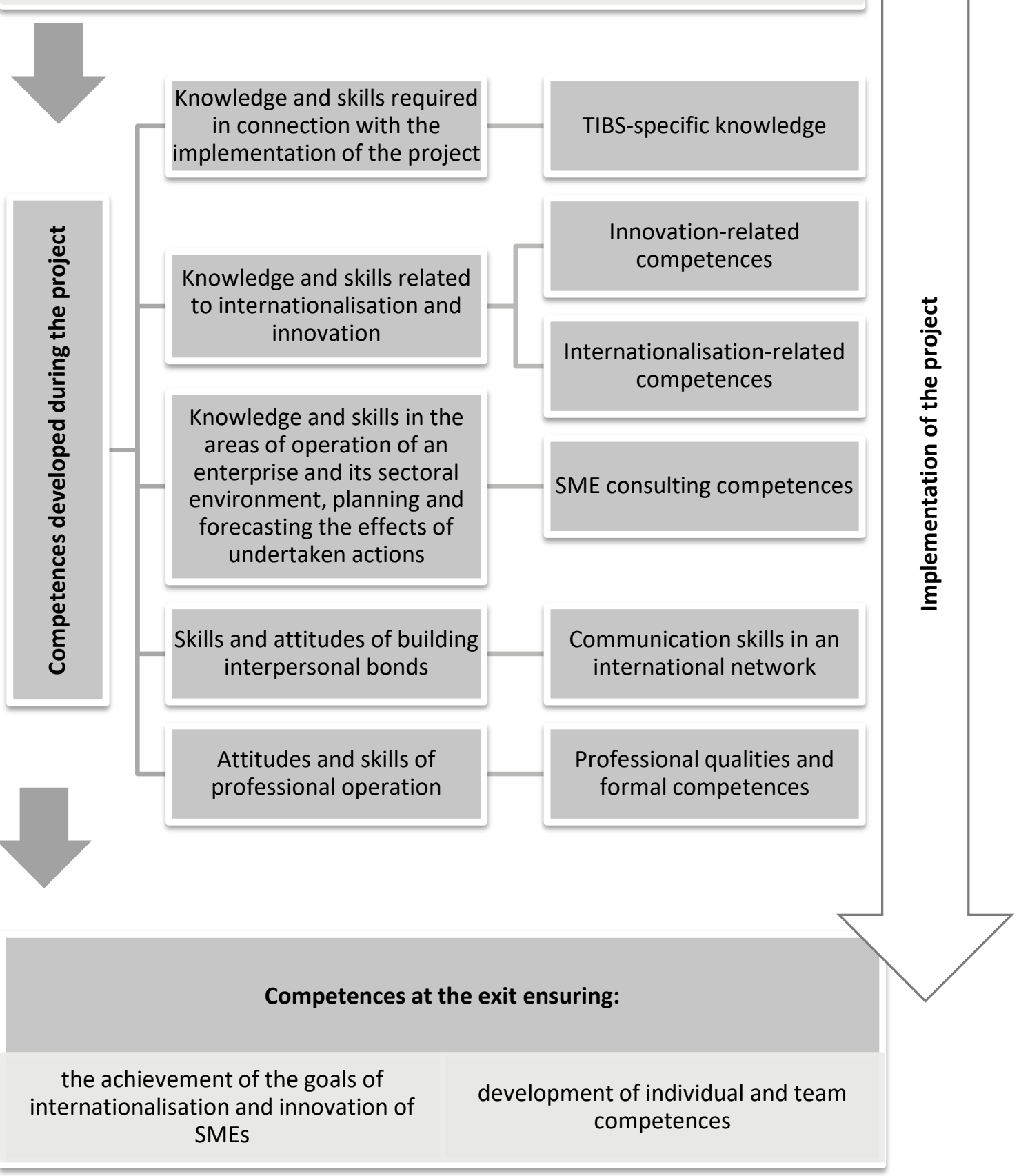

Fig. 10. Model of competences of international innovation brokers 
A graphic presentation of the competency model of international innovation brokers is given in Fig. 10. Overall, it can be said that many SMEs can only access external knowledge sources with the help of actors who are well connected to the global sources of knowledge so that they can translate information into a form that is understandable to local organisations. This is one of the reasons to expand the activities of international innovation brokers. In the project, their competences were developed and used to build a network of international cooperation, to integrate individual knowledge, and used for the internationalisation and implementation of innovation in SMEs, which is the overall goal of the project. The authors did not specify the degree of importance of the detailed competence elements and their components, thus giving them equal importance in the process of accelerating the internationalisation of SMEs and the implementation of innovations. Based on the proposed model, the competences of brokers are largely based on knowledge and skills. The authors assumed that this model, built on the basis of the experience gained during the GoSmart BSR project, is an inspiration to experiment and introduce new ideas and concepts. The identified competence elements can be considered universal and key in the work of an international innovation broker, yet their list and components of competences are inexhaustive. The issues discussed in the article require further research.

\section{CONCLUSIONS}

The article presents a pragmatic model approach to the competences of international innovation brokers. This approach is an attempt to describe them and can be considered a research field that requires further study. GoSmart BSR project partners did not use ready-made solutions when creating it. Instead, they undertook a search to match the model solution to the assumptions and goals of the project. As a result of the conducted research and analyses, a sixelement competency model was developed. The authors are aware of many limitations of the presented research approach. The research, although carried out on the scale of one project, may constitute a reference point for other networks of collaborating entities on an international scale for the internationalisation and innovation of SMEs. The proposed model of competences of international innovation brokers can be used in practice to set target conditions for their recruitment. Of course, all models are limited in vari- ous respects. Nevertheless, both an organisation and individual employees gain the opportunity to independently check what is expected of them and what knowledge and skills should be acquired. When used in a recruitment strategy, the model makes it easier to find suitable candidates for a broker position and, at the same time, indicates investing in creating an environment that will enable them to perform their duties. Further empirical research based on the model presented in the article is certainly necessary.

Another important issue is the flow of knowledge in regional network systems. This is because of problems of global knowledge sources, especially emerging in less developed regions, the creation of network structures optimal for the flow of knowledge, and knowledge transformation so that it can be adapted by local companies from the region covered by the project, i.e., the Baltic Sea Region. The premise is, therefore, that knowledge brokers are not only able to initiate collaboration that involves the flow, exchange and creation of knowledge but also participate actively in it. The processes of flow, exchange and creation of knowledge are influenced by the obtained knowledge resources and the skills in applying them to solving new problems and choosing the optimal solution.

\section{ACKNOWLEDGEMENTS}

This research was supported by the project 'Strengthening smart specialisation by fostering transnational cooperation (GoSmart BSR)' which has received funding from the European Union Interreg Baltic Sea Region Programme 2014-2020.

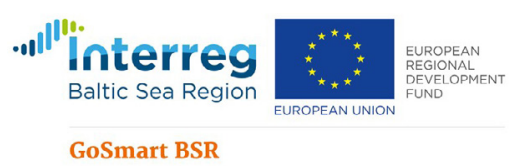

The publication of the article for 11th International Conference on Engineering, Project, and Production Management - EPPM2021 was financed in the framework of the contract no. DNK/ SN/465770/2020 by the Ministry of Science and Higher Education within the "Excellent Science" programme.

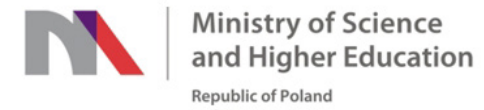




\section{LITERATURE}

Abraham, S. E., Karns, L. A., Shaw, K., \& Mena, M. A. (2001). Managerial competencies and the managerial performance appraisal process. Journal of Management Development, 20, 842-852. doi: $10.1108 / 02621710110410842$

Andersson, S., Gabrielsson, J., \& Wictor, I. (2004). International activities in small firms: examining factors influencing the internationalization and export growth of small firms. Canadian Journal of Administrative Sciences, 21(1), 22-34. doi: 10.1111/J.19364490.2004.TB00320.X

Barkun, Y. (2019). Competencies of talents: bibliometric analysis. Akademia Zarządzania, 3(2), 6-15.

Baruah, J., \& Paulus, P. (2019). Collaborative Creativity and Innovation in Education. In C. A. Mullen (Ed.), Creativity Under Duress in Education? Resistive Theories, Practices, and Actions (pp. 155-177). Cham, Switzerland: Springer. doi: 10.1007/978-3-319-90272-2_9

Bergenhenegouwen, G. J., ten Horn, H. F. K., \& Mooijman, E. A. M. (2020). Competence development - a challenge for HRM professionals: core competences of organizations as guidelines for the development of employees. Journal of European Industrial Training, 20(9), 29-35. doi: 10.1108/03090599610150282

Bhardwaj, A., \& Punia, B. K. (2013). Managerial competencies and their influence on managerial performance: a literature review. International Journal of Advanced Research in Management and Social Sciences, 2(5), 70-84.

Bogers, M., Chesbrough, H., \& Moedas, C. (2018). Open innovation: Research, Practices and Policies. California Management Review, 60(2), 5-16. doi: $10.1177 / 0008125617745086$

Boyack, K. W., Klavans, R., \& Börner, K. (2005). Mapping the backbone of science. Scientometrics, 64(3), 351374. doi: 10.1007/s11192-005-0255-6

Brelik, A., \& Żuchowski, I. (2017). Competencies of contemporary managers. Folia Pomeranae Universitatis Technologiae Stetinensis, Oeconomica, 89(4), 15-28. doi: 10.21005/oe.2017.89.4.02

Byron, K. (2012). Creative reflections on brainstorming. London Review of Education, 10(2), 201-213. doi: $10.1080 / 14748460.2012 .691284$

Casanovas, M. M., Miralles, F., Garcia, R., \& Gómez, M. (2011). Innovation Factory Brainstorming: improving idea generation through experiential learning training. Conference: XXII ISPIM Conference: Sustainability in Innovation. Hamburg, Germany: Hamburg University of Technology.

Castriotta, M., Loi, M., Marku, E., \& Moi, L. (2021). Disentangling the corporate entrepreneurship construct: conceptualizing through co-words. Scientometrics, 126, 2821-2863. doi: 10.1007/s11192-020-03846-2

Chaochotechuang, P., Daneshgar, F., \& Mariano, S. (2019). External knowledge search paths in open innovation processes of small and medium enterprises. European Journal of Innovation Management, 23(3), 524550. doi: 10.1108/EJIM-01-2019-0013
Chyung, S. (2005). Human performance technology from Taylor's scientific management to gilbert's behavior engineering model. Computer Science, 44(1), 23-28. doi: 10.1002/PFI.4140440109

Cobo, M. J., López-Herrera, A. G., Herrera-Viedma, E., \& Herrera, F. (2011). Science Mapping Software Tools: Review, Analysis, and Cooperative Study Among Tools. Journal of the American Society for Information Science and Technology, 62(7), 1382-1402. doi: 10.1002/asi.21525

Crupi, A., Del Sarto, N., Di Minin, A., Gregori, J. L., Lepore, D., Marinelli, L., \& Spigarelli, F. (2020). The digital transformation of SMEs - a new knowledge broker called the digital innovation hub. Journal of Knowledge Management, 6, 263-1288. doi: 10.1108/JKM11-2019-0623

Dagnino, G. B., Levanti, G., \& Picone, P. M. (2015). Interorganizational network and innovation: a bibliometric study and proposed research agenda. Journal of Business \& Industrial Marketing, 30(3/4), 354-377. doi: 10.1108/JBIM-02-2013-0032

Dingle, J. (1995). Analysing the competence requirements of managers. Management Development Review, 8(2), 30-36. doi: 10.1108/09622519510082028

Edwards, T., Delbridge, R., \& Munday, M. (2005). Understanding Innovation in Small and Medium-Sized Enterprises: A Process Manifest. Technovation, 25(10), 1119-1127. doi:10.1016/j.technovation.2004.04.005

Filipowicz, G. (2016). Zarządzanie kompetencjami. Perspektywa firmowa $i$ osobista [Competence management. Company and personal perspectives]. Warszawa, Poland: Wolters Kluwer.

Gaviria-Marin, M., Merigó, J. M., \& Baier-Fuentes, H. (2019). Knowledge management: A global examination based on bibliometric analysis. Technological Forecasting \& Social Change, 140, 194-220. doi: 10.1016/j.techfore.2018.07.006

Glänzel, W. (2003). Bibliometrics as a research field: A course on theory and application of bibliometric indicators. Leuven, Belgium: Course Handouts.

Gonczi, A., \& Hager, P. (2010). The Competency Model. In P. Peterson, E. Baker \& B. McGaw (Eds.), International Encyclopedia of Education. Third Edition (pp. 403-410). Amsterdam, Netherlands: Elsevier.

Halicka, K. (2017). Main concepts of technology analysis in the light of the literature on the subject. Procedia Engineering, 182, 291-298. doi: 10.1016/j.proeng.2017.03.196

Halvarsson Lundkvist, A., \& Gustavsson, M. (2018). The role of brokers in a workplace development programme targeting SMEs. European Journal of Training and Development, 42(7/8), 417-434. doi: 10.1108/ EJTD-04-2018-0037

Harland, C. M., \& Knight, L. A. (2001). Supply network strategy. Role and competence requirements. International Journal of Operations \& Production Management, 21(4), 476-489. doi: 10.1108/01443570110381381

Hass, A. (2015). Crowding at the frontier: boundary spanners, gatekeepers and knowledge brokers. Journal of Knowledge Management, 19(5), 1029-1047. doi: 10.1108/JKM-01-2015-0036 
He, Q. (1999). Knowledge Discovery Through Co-Word Analysis. Library Trends, 48(1), 133-159.

Hilliges, O., Terrenghi, L., Boring, S., \& Kim, D. (2007). Designing for collaborative creative problem solving. In B. Shneiderman (Ed.), Proceedings of the 6th Conference on Creativity \& Cognition (pp. 137146). New York, United States: Association for Computing Machinery. doi: 10.1145/1254960. 1254980

Hogeforster, M. (2014). Future Challenges for Innovations in SME in the Baltic Sea Region. Procedia Social and Behavioral Sciences, 110, 241-250. doi:10.1016/j.sbspro.2013.12.867

Idiagbon-Oke, M., \& Oke, A. (2019). Investigating broker centrality in innovation-driven networks. Journal of Manufacturing Technology Management, 31(3), 599619. doi: 10.1108/JMTM-08-2019-0291

Janiszewski, A. (2019). Types of models of activities of knowledge brokers. Scientific Papers of Silesian University of Technology, Organization and Management Series, 136, 165-178. doi: 10.29119/16413466.2019.136.14

Jurek, P. (2012). Metody pomiaru kompetencji zawodowych [Methods for measuring professional competence]. Warszawa, Poland: Ministerstwo Pracy i Polityki Społecznej.

Klincewicz, K., Żemigała, M., \& Mijal, M. (2012). Bibliometria $w$ zarzadzaniu technologiami i badaniami naukowymi [Bibliometrics in technology and research management]. Warszawa, Poland: Ministerstwo Nauki i Szkolnictwa Wyższego.

Kononiuk, A., \& Magruk, A. (2008). Przegląd metod i technik badawczych stosowanych $\mathrm{w}$ programach foresight [Overview of research methods and techniques used in foresight programmes]. Nauka i Szkolnictwo Wyższe, 2(32), 28-40.

Krajcovicova, K., Caganova, D., \& Cambal, M. (2012). Key managerial competencies and competency models in industrial enterprises. In B. Katalinic (Ed.), Annals of DAAAM for 2012 \& Proceedings of the $23 \mathrm{rd}$ International DAAAM Symposium, 23(1), (pp. 11191122). Vienna, Austria: DAAAM International.

Kruse, M., Urban, W., Girejko, R., \& Wedemeier, J. (2019). Methodology for Transnational Smart Specialisation Strategy. Retrieved from: https://gosmartbsr.eu/ methodology-for-transnational-smart-specialisation-strategy/

Kupczyk, T., \& Stor, M. (2017). Competency Management theory, research \& business practice. Wrocław, Poland: University of Business in Wroclaw.

Leick, B., \& Gretzinger, S. (2020). Business networking in organisationally thin regions: a case study on network brokers, SMEs and knowledge-sharing. Journal of Small Business and Enterprise Development, 27(5), 839-861. doi: 10.1108/JSBED-12-2019-0393

Lenart-Gansiniec, R. (2018). Kompetencje kreatywne społeczności wirtualnych $\mathrm{w}$ crowdsourcingu [Creative competences of virtual communities in crowdsourcing]. Studia $i$ Prace Kolegium Zarządzania $i$ Finansów, 161, 175-186.

Lis, A. (2019). Leadership and Corporate Social Responsibility: Mapping the Conceptual Structure of Re- search. Journal of Corporate Responsibility and Leadership, 6(1), 7-21. doi: 10.12775/JCRL.2019.001

Loufrani-Fedida, S., \& Aldebert, B. (2021). A multilevel approach to competence management in innovative small and medium-sized enterprises (SMEs): literature review and research agenda. Employee Relations, 43(2), 507-523. doi 10.1108/ER-04-2020-0173

Macchi, M., Rizzo, U., \& Ramaciotti, L. (2014). From services dealers to innovation brokers. How open innovation paradigm affects incubator activities. Evidence from Italy. Journal of Intellectual Capital, 15(4), 554-575. doi: 10.1108/JIC-06-2014-0078

Moczydłowska, J. M. (2008). Zarządzanie kompetencjami zawodowymi a motywowanie pracowników [Professional competence management and employee motivation]. Warszawa, Poland: Difin.

Moczydłowska, J. M., \& Serafin, K. (2016). Doskonalenie kompetencji zawodowych $w$ profesjonalnie zarządzanej organizacji [Improving professional competence in a professionally managed organisation]. Katowice, Poland: Wydawnictwo Naukowe Sophia.

Mueller-Using, S., Urban, W., \& Wedemeier, J. (2020). Internationalization of SMEs in the Baltic Sea Region: Barriers of cross-national collaboration considering regional innovation strategies for smart specialization. Growth and Change, 51(4), 1471-1490. doi: 10.1111/grow.12439

Mundim, A., Stocchetti, A., \& Rossi, A. (2000). SMEs in Global Market: Challenges, Opportunities and Threats. Brazilian Electronic Journal of Economics, 3(1), 1-21.

Papulová, Z., \& Mokroš, M. (2007). Importance of managerial skills and knowledge in management for small entrepreneurs. Prague: E-Leader. Retrieved from: https://www.g-casa.com/PDF/Papulova-Mokros.pdf

Patanakul, P., \& Milosevic, D. (2008). A competency model for effectiveness in managing multiple projects. Journal of High Technology Management Research, 18(2), pp. 118-131. doi: 10.1016/j.hitech.2007.12.006

Paulus, P., Dzindolet, M., \& Kohn, N. W. (2011). Collaborative Creativity - Group Creativity and Team Innovation. In M. D. Mumford (Ed.), Handbook of Organizational Creativity (pp. 327-357). Amsterdam, Netherlands: Elsevier. doi: 10.1016/B978-0-12374714-3.00014-8

Prahalad, C. K., \& Hamel, G. (1990). The Core Competence of the Corporation. Harvard Business Review, 68(3), 79-91. doi: 10.1016/B978-0-7506-7088-3.50006-1

Prasanna, R., Samarakoon, J., Naradda Gamage, S. K., Ekanayake, E., Rajapakshe, P., \& Abeyrathne, G. (2019). Sustainability of SMEs in the Competition: A Systemic Review on Technological Challenges and SME Performance. Journal of Open Innovation: Technology, Market, and Complexity, 5(100), 1-18. doi: 10.3390/joitmc5040100

Putman, V. L., \& Paulus, P. (2009). Brainstorming, Brainstorming Rules and Decision Making. The Journal of Creative Behavior, 43(1), 1-17. doi: 10.1002/j.21626057.2009.tb01304.x

Pyka, J., \& Janiszewski, A. (2016). Brokerzy w przepływie wiedzy. Kontekst regionalny [Brokers in knowledge flows. Regional context]. Studia Ekonomiczne. Zeszy- 
ty Naukowe Uniwersytetu Ekonomicznego w Katowicach, 280, 157-171.

Robotham, D., \& Jubb, R. (1996). Competences: measuring the unmeasurable. Management Development Review, 9(5), 25-29. doi: 10.1108/09622519610131545

Sergeeva, N., \& Liu, N. (2020). Social construction of innovation and the role of innovation brokers in the construction sector. Construction Innovation, 20(2), 247-259. doi: 10.1108/CI-02-2019-0016

Siderska, J., \& Jadaa, K. S. (2018). Cloud manufacturing: a service-oriented manufacturing paradigm. A review paper. Engineering Management in Production and Services, 10(1), 22-31. doi: 10.1515/emj-2018-0002

Singh, R. K., \& Deshmukh, S. G. (2008). Strategy Development by SMEs for Competitiveness: A Review. Benchmarking International Journal, 15, 525-547. doi:10.1016/j.sbspro.2015.01.289

Srivastava, M. (2020). The influence of brokers on networking behaviour during internationalization: a study of Czech SMEs. Journal of Business \& Industrial Marketing, 36(3), 436-453. doi: 10.1108/JBIM-09-2019-0405

Staškeviča, A. (2019). The Importance of Competency Model Development. Acta Oeconomica Pragensia, 2, 62-71. doi: $10.18267 /$ j.aop.622

Stolovitch, H. D. (2000). Human Performance Technology: Research and Theory to Practice. Performance Improvement, 39(4), 7-16. doi: 10.1002/pfi.4140390407

Sudolska, A. (2006). Zasoby wiedzy jako strategiczny czynnik międzynarodowej konkurencyjności przedsiębiorstwa [Knowledge resources as a strategic factor of international competitiveness of a company]. In M. J. Stankiewicz (Ed.), Zarzadzanie wiedza jako kluczowy czynnik międzynarodowej konkurencyjności przedsiębiorstwa [Knowledge management as a key factor of international competitiveness of a company] (pp. 63-114). Toruń, Poland: Dom Organizatora.

Sweileh, W. M., Shraim, N. Y., Al-Jabi, S. W., Sawalha, A. F., Rahhal, B., Khayyat, R. A., \& Zyoud, S. H. (2016). Assessing worldwide research activity on probiotics in pediatrics using Scopus database: 1994-2014. World Allergy Organization Journal, 9(1), 1-12. doi: 10.1186/s40413-016-0116-1

Szczepańska-Woszczyna, K. (2016). Kompetencje menedżerskie $w$ kontekście innowacyjności przedsiebiorstwa [Managerial competences in the context of company innovation]. Warszawa, Poland: PWN.

Szpilko, D. (2017). Tourism Supply Chain-Overview of Selected Literature. Procedia Engineering, 182, 687693. doi: 10.1016/j.proeng.2017.03.180

Szydło, J. (2018). Kulturowe ramy zarządzania. Katowice: Wydawnictwo Naukowe Sophia.

Szydło, J., Grześ-Bukłaho, J. (2020). Relations between National and Organisational Culture - Case Study. Sustainability, 12 (4), 1-22. doi:10.3390/su12041522

Taşkin, Z., \& Aydinoglu, A. U. (2015). Collaborative interdisciplinary astrobiology research: a bibliometric study of the NASA Astrobiology Institute. Scientometrics, 103(3), 1003-1022. doi: 10.1007/s11192-015$1576-8$
Thompson, P. (2003). Improving the Creativity of Organizational Work Groups. Academy of Management Perspectives, 17(1), 96-111. doi: 10.5465/ AME.2003.9474814

Tidd, J., \& Bessant, J. (2013). Zarządzanie innowacjami. Integracja zmian technologicznych, rynkowych i organizacyjnych [Innovation management. Integrating technological, market and organisational change]. Warszawa, Poland: Oficyna Wolters Kluwer business.

Trias de Bes, F., \& Kotler, Ph. (2013). Innowacyjność przepis na sukces. Model „Od A do F” [Innovation a recipe for success. The „A to F” model]. Poznań, Poland: Dom Wydawniczy Rebis.

Vakola, M., Soderquist, K. E., \& Prastacos, G. (2007). Competency management in support of organisational change. International Journal of Manpower, 28(3/4), 260-275. doi: 10.1108/01437720710755245

van Eck, N. J., \& Waltman, L. (2007). VOS: a new method for visualizing similarities between objects, studies in classification data analysis, and knowledge organization. Berlin, Heidelberg, Germany: Springer.

van Eck, N. J., \& Waltman, L. (2010). Software survey: VOSviewer, a computer program for bibliometric mapping. Scientometrics, 84, 523-538. doi: 10.1007/ s11192-009-0146-3

Waltman, L., van Eck, N. J., \& Noyons, E. C. (2010). A unified approach to mapping and clustering of bibliometric networks. Journal Informetr, 4(4), pp. 629635. doi: 10.1016/j.joi.2010.07.002

Wang, H., Fussell, S. R., \& Cosley, D. (2010). Idea expander: Supporting group brainstorming with conversationally triggered visual thinking stimuli. In K. Inkpen \& C. Gutwin (Eds.), Proceedings of the 2010 ACM Conference on Computer Supported Cooperative Work, CSCW 2010 (pp. 103-106). Savannah, Georgia, USA: Association for Computing Machinery. doi: $10.1145 / 1718918.1718938$

Winkowska, J., Szpilko, D., \& Pejić, S. (2019). Smart city concept in the light of the literature review. Engineering Management in Production and Services, 11(2), 70-86. doi:10.2478/emj-2019-0012

Youngblood, M. \& Lahti, D. (2018). A bibliometric analysis of the interdisciplinary field of cultural evolution. Palgrave Communications, 4(1), 1-10. doi:10.1057/ s41599-018-0175-8

Zupic, I. \& Čater, T. (2015). Bibliometric Methods in Management and Organization. Organizational Research Methods, 18(3), 429-472. doi: $10.1177 / 1094428114562629$ 